\title{
Measuring the Impact of Learning Organization on Employee Retention, Competitive Advantage and Financial Performance in the BPO industry
}

\author{
Rajesh N. Pahurkar, Jaya Nair, Ashutosh Kolte
}

\begin{abstract}
In knowledge intensive industries such as the Business process Outsourcing and the Offshoring or shared service centres, the approach to learning has a significant role to play in deriving competitive advantage from domain experts who have had exposure to multiple clients who may have had a presence across the globe. The organizational experience gathered over a period of time is most relevant when redesigning processes, leveraging automation and driving business impact through higher revenue for the clients. The BPO industry is at a point of inflection where retaining top performers to showcase deep domain expertise, access to technology and a learning culture can be a huge differentiator that influences client's choice of vendor partners. The current paper provides a Learning organization framework and establishes a link with indicators of organizational performance - employee retention, competitive advantage and financial performance. $A$ questionnaire survey of managers from the BPO sector in India has been conducted. The findings indicate a that a robust learning organization is critical to retaining talent and gaining competitive advantage both of which have a mediating effect on the financial performance of the organization. Conclusions have been drawn from the statistical analysis and implications for the industry have been recommended.
\end{abstract}

Keywords : Learning organization, Competitive advantage, Employee Retention, Financial Performance, Organizational performance.

\section{INTRODUCTION}

Global competition, regulations, and changing technology reinforce the need for outsourcing companies to reinvent themselves and re-imagine business processes as they adapt to end-customer needs and adopt technological advances. Innovation can have an immediate impact on organizational performance (Hult et al., 2004; Kleinschmidt, Cooper, Elko, 2000; Erdil et al., 2004; Rubera and Kirca 2012). Innovation in products and services is crucial for sustained competitive advantage and organizational performance (Dougherty and Hardy, 1996). In the BPO industry where client demands and profit margins drive innovation, the ability to leverage experiential learning and domain knowledge can influence

Revised Manuscript Received on October 15, 2019.

* Correspondence Author

Rajesh N. Pahurkar, Associate Professor, Department of Management Sciences (PUMBA), Savitribai Phule, University of Pune, Maharashtra, India.

Jaya Nair, Research Student, Department of Management Sciences (PUMBA), Savitribai Phule, University of Pune, Maharashtra, India.

Ashutosh Kolte, Assistant Professor, Department of Management Sciences (PUMBA), Savitribai Phule, University of Pune, Maharashtra, India. client confidence and contract renewal. Research in the past focused on external factors developing a market based view of competitive advantage (Porter 1985), and some focused on the internal factors developing a Resource based view of competitive advantage (Barney, 1991). Intangibles such as Organizational processes, attitude towards learning, Knowledge management practices, Organizational behaviour and Human Resource policies are as much a part of the internal resources as are the moveable and immovable assets. Building a robust learning and development process, is detrimental to encouraging Organizational Learning, Team learning and Individual learning. An organization that has developed these structures is able to successfully leverage the knowledge that resides within its teams to strategically align learning goals with the organizational objectives; these qualify as a Learning Organizations. Retaining employees who have a deep understanding of the domain is crucial to reimagining service delivery using automation tools to improve quality of service and impacting revenue. Offering a work environment that encourages self-development by providing learning opportunities can be a major retention strategy. Skilling for jobs of the future and building a environment that encourages constant up-skilling encourages high performers to stick with the organization and grow with it. This ability to innovate can be a source of competitive advantage as clients look for vendor partners who can engage with them in the digital transformation journey. The current study attempts to understand the link between Learning organizations and competitive advantage, employee retention and financial performance.

\section{THEORETICAL BACKGROUND}

The concept of Learning Organization was developed by Peter Senge (1990) to identify organizations which facilitate the learning of its members and continuously transform themselves by achieving personal mastery, team learning, overcoming mental models and nurturing a shared vision. Senge introduced the fifth element 'system's thinking' that integrated all the four elements together and helped see the bigger picture. David Garvin built on this idea and highlighted that continuous improvement requires a commitment to learning (Garvin, 1994). Organizational culture that is transparent, rewards performance and encourages experimentation is the hallmark of a Learning organization (Gephart, 1996). A mature leadership that mentors its team, ensures personal goals are aligned with the organizational goals and encourages and rewards shared learning is able to retain its best 
talent. Integrating external learning with individual experience and evolving technology can stimulate novel ideas and usher in transformation (Levitt \& March, 1996) managed through robust systems, processes and routines and become competitive (Argyris and Schon, 1996).

In the BPO industry, domain expertise developed over time can positively impact the success of the organization through innovative products and services that can be commercially exploited. Some of the gaps in the older models all of which have their origins in the west and the manufacturing world, were built in a static external environment. Senge freezes on a couple of variables to the exclusion of some other behavioural traits that can influence organizational learning. None of these models have been applied to the BPO industry, where talent mobility has been a major challenge. The 'what's in it for me' or the WIIFM factor has been given a complete miss. Some of these gaps have been addressed in the model for the VUCA world that has been proposed (Nair \& Pahurkar, 2016). The attributes and characteristics of a learning organization applicable for the BPO industry are Organizational environment, External connect, Transformational Leadership, entrepreneurial orientation, Organizational Learning and Knowledge Management (Nair $\&$ Pahurkar, 2016). This model takes into account the need to stay constantly connected with the external environment where evolving technology is a constant threat, the role of transformational leader engaged with the team and creating a positive work environment; need for entrepreneurial mind-set to drive innovation from within; time for reflection and shared learning and robust knowledge management framework.

Developing the workforce in the BPO by investing in skill enhancement and leveraging latent capabilities dormant within the organization in order to gain competitive advantage becomes possible when the high performers are retained by the organization. Learning Organizations proactively, up-skill the workforce and empower them with the competencies required to re-imagine their business, innovate and provide value, that can bring in competitive advantage. BPO employees who are acutely aware of the threat posed by digitalization of work are seeking learning opportunities to up-skill themselves for the jobs of the future. With the arrival of disruptive technologies and changing workforce demographics, re-skilling by investing in Learning and development can become a great retention strategy since the high potential members on the team, who are capable of new ideas and creative thinking, and are constantly surveying the landscape to enhance their skills and stay relevant. Based on the observations presented we hypothesize that:

\section{H1: Learning organizations and employee retention is significantly related}

The capacity of the organization to coordinate, orchestrate and deploy its knowledge sources to create value as it pursues its vision for the future is the intellectual capital of the organization (Kaufmann and Schneider, 2004). The ability of organizations to acquire, integrate and reconfigure its resources in response to growing and changing customer demands can lead to sustained competitive advantage. The resource based view (RBV) (Barney, 2002) of competitive advantage proposes that sustained profitability of an organization depends upon the creation, development and implementation of unique resources and capabilities. When organizations build efficient systems and processes that enable fast development of new products and services, and also have a high rate of employee retention, they are able to maintain a sustainable cost advantage which can result in high profitability, this is its 'competitive advantage'.As organizations garner unique capabilities to the exclusion of competitors, there is an improvement in its relative performance (Urbano \& Yordanova, 2008), thus the intellectual capital is being deployed to create organization wealth (Arenas et, al, 2008). Based on the observations presented we hypothesize that:

H2: Learning organizations and competitive advantage is significantly related

Learning organizations focus on embedding learning in the DNA of the organization culture. This encourages reflection ideation and an entrepreneurial orientation amongst the members. The successful mobilization of this knowledge leads to competitive advantage, as the focus is on value maximization through agility, enhanced products, and dynamic capabilities (Freeman, 2001). The knowledge worker, develops a high innovation quotient that equipsthe organization with the ability to respond to change with agility (Watkins and Marsick, 1999). Learning organizations provide the right mechanism for enhancing, organizational effectiveness, by providing a nurturing environment for its workforce making it an attractive place with mentoring leaders and opportunities for development. Enhanced opportunities for value generation and a strong market position leads to increase in revenue and thereby positive influence on financial performance. Based on the observations presented we hypothesize that:

H3: Learning organizations and financial performance is significantly related

Research plan and survey instrument:

Interviews with employees from the BPO industry from functions such as Business development, Learning and development, Talent Acquisition, Talent Management and Delivery, helped gather insights into value placed on knowledge, experience, and innovation by the team. Informal discussions with clients had also helped develop an understanding on service differentiators and what clients expect from their vendor partner. The questionnaire was developed based on the six characteristics identified in the LO model - Knowledge Management, entrepreneurial Orientation, Transformational Leadership, organizational learning, external connect and organizational environment. Indicators of employee retention were learning opportunities built along the principles of adult learning principles, self-development and sensitivity towards employee grievance. The resource based view of competitive advantage (Barney (1991) was assessed by looking at how valuable, rare, inimitable and well organized were the organization's resources. The responses were measured on a five point Likert scale (Strongly disagree - Strongly Agree). Open ended questions were not included, but were replaced with multiple choice questions, the options for which were based on inputs received during the interviews. Questions that help 
profile the respondents were added.

This model has been adopted to gauge the relationship between a learning organization and employee retention, competitive advantage and financial performance. The population for this pilot study comprised of 50 Managers from Domestic BPOs, Shared service centres, IT based Service provider, and pure play BPOs. The population of this study included 8 organizations, with respondents from 6 cities across India. The samples characteristics were reflective of all 3 outsourcing organizations (IT based, Pure play, domestic BPO and) and one offshoring organization (shared service centres also referred to as Captive centres) in India. 20\% from Domestic BPOs, 20\% Shared service centres, $30 \%$ IT based service provider, and 30\% from pure play BPOs. The domains being supported by the in-scope organizations included BFSI, Healthcare Utilities, Telecom and Hospitality. Organizations providing tech- support from India were excluded from the current scope of study.The Methodology adopted for data collection involved in person meetings and telephonic interviews. Each discussion was preceded by a 10 minute context setting discussion, highlighting the importance and need for the study given the changing customer expectations and technological advances. The model fit, reliability and validity of the model was analysed using Fit indices such as Good fit index, Competitive fit index, and root mean residual; Cronbach's alpha, and Confirmatory path analysis technique with SPSS package.

\section{DATA ANALYSIS AND RESULTS}

The reliability and Validity of the survey instrument developed using the nine latent variables was established using Cronbach's $\alpha$ and Confirmatory Analysis. The relation between Learning organizations, Competitive advantage was established using the Canonical Correlation. To assess the link between Learning Organizations and Financial Performance was established through statistical Path analysis.

\section{A.Establishing the Reliability and Validity of the questionnaire with sample data \\ I. Reliability}

Reliability is the ability of the scale to produce consistent results. In the current study 9 latent constructs are used to seek answers to the research question, whether the learning strategies adopted by BPOs in India will bring them competitive advantage when competing for business in a rapidly changing environment.

These nine latent constructs are:
1. Organizational Environment (OE)
2. External Connect (EC)
3. Entrepreneurial Orientation (EO)
4. Knowledge Management (KM)

5. Organizational learning (OL)

6. Transformational leadership (TL)

7. Competitive Advantage (CA)

8. Employee Retention (Rt)

9. Financial performance (FP)

For latent construct reliability is the extent to which the latent constructs correlate internally. In the current study reliability is assessed using Cronbach's $\alpha$. Cronbach's $\alpha$ is a largely used statistical technique to confirm reliability of the instrument.

Cronbach's $\alpha$ value $>0.7$ indicates that the items of the construct have high internal consistency.

The following table provides information on the number of items used to define each latent item under study and the Cronbach's $\alpha$ value.

\begin{tabular}{|l|l|l|}
\hline Construct & $\begin{array}{l}\text { Number } \\
\text { items }\end{array}$ & \multicolumn{2}{|l|}{$\begin{array}{l}\text { Cronbach's } \\
\alpha\end{array}$} \\
\hline $\begin{array}{l}\text { Entrepreneurial } \\
\text { Orientation }\end{array}$ & 5 & 0.795 \\
\hline Environment & 5 & 0.772 \\
\hline External Connect & 5 & 0.793 \\
\hline Knowledge Management & 5 & 0.868 \\
\hline Organizational learning & 5 & 0.830 \\
\hline $\begin{array}{l}\text { Transformational } \\
\text { leadership }\end{array}$ & 5 & 0.837 \\
\hline Competitive Advantage & 5 & 0.926 \\
\hline Employee Retention & 5 & 0.854 \\
\hline Financial Performance & 5 & 0.801 \\
\hline
\end{tabular}

The above table reveals that it can be seen that all constructs have a Cronbach's $\alpha$ above the threshold value of 0.7 . Hence it can be concluded that each instrument used to measure the construct is consistent and highly reliable.

\section{Validity}

Validity is the ability of the scale to produce accurate results and is the extent to which the scale measures what it is supposed to measure. Reliability and Validity are quality assessment for instruments measuring variables and constructs under the study. If the scale is not reliable and valid the results of the statistical analysis may be dubious.

Confirmatory factor analysis is used to assess validity for constructs under study.

Confirmatory Factor analysis is a special form of factor analysis used for testing whether measures of a construct are consistent with the researcher's understanding about the nature of construct or factor. It helps in testing if data fits the hypothesized model. 
Measuring the Impact of Learning Organization on Employee Retention, Competitive Advantage and Financial Performance in the BPO industry

Confirmatory Factor analysis for the nine latent variables

\begin{tabular}{|c|c|c|c|c|c|c|c|c|c|c|}
\hline Fit Indices & $\begin{array}{l}\text { Criteria of } \\
\text { Acceptance }\end{array}$ & EO & OE & EC & $\mathbf{K M}$ & OL & $\mathbf{T L}$ & $\mathbf{C A}$ & $\mathbf{R t}$ & FP \\
\hline $\begin{array}{l}\text { CMIN/DF } \\
\text { (Minimum } \\
\text { discrepancy as } \\
\text { indexed } \\
\text { chi-square) } \\
\end{array}$ & Less than 5 & 0.905 & 1.764 & 2.559 & 2.091 & 0.035 & 2.144 & 1.852 & 3.766 & 2.626 \\
\hline $\begin{array}{l}\text { CFI } \\
\text { (Competitive } \\
\text { Fit Index) }\end{array}$ & $\begin{array}{l}\text { More than } 0.9 \text { for } \\
\text { good fit, between } \\
0.9 \text { to } 0.8 \text { for } \\
\text { borderline fit }\end{array}$ & 1 & 0.94 & 0.903 & 0.962 & 1 & 0.935 & 0.981 & 0.9 & 0.914 \\
\hline $\begin{array}{l}\text { GFI (Goodness } \\
\text { of Fit index) }\end{array}$ & More than 0.9 & 0.965 & 0.932 & 0.918 & 0.923 & 0.985 & 0.917 & 0.927 & 0.9 & 0.91 \\
\hline $\begin{array}{l}\text { RMR (Root } \\
\text { mean residual) }\end{array}$ & $\begin{array}{l}\text { Less than } 0.08 \text { for } \\
\text { adequate fit, } \\
\text { between } 0.08 \text { and } \\
\text { less than } 0.1\end{array}$ & 0 & 0.077 & 0.099 & 0 & 0.035 & 0.091 & 0.042 & 0.1 & 0.1 \\
\hline
\end{tabular}

All the above Fit indices suggest a good fit between sample data and hypothetical model; hence the validity of the instrument is established.

\section{B. Hypothesis testing}

I. Learning organizations and employee retention is significantly related

Statistical Test: Canonical Correlation

Variables and Measurement:

Learning organization is a latent variable measured using 6 variables.
Retention is also a latent variable with 5 measureable indicators

\section{Hypotheses:}

H0: Learning organization and employee retention is not interrelated

H1: Learning organizations and employee retention is significantly related

$$
\alpha=0.05
$$

\section{Canonical Correlations}

\begin{tabular}{|l|l|l|l|l|l|l|l|}
\hline Sr No. & Correlation & Eigenvalue & Wilks Statistic & F & Num D.F & Denom D.F. & Sig. \\
\hline 1 & .670 & .815 & .361 & 1.526 & 30.000 & 158.000 & .051 \\
\hline 2 & .421 & .215 & .656 & .906 & 20.000 & 133.615 & .580 \\
\hline
\end{tabular}

- Since $p=0.05$, null hypotheses is rejected and it is concluded that the two variables are inter related

$\mathrm{R}^{2}=0.44$; this indicates that Learning Organization can explain $44.8 \%$ of the Retention Variables

\section{Learning organizations and competitive advantage is significantly related}

Statistical Test: Canonical Correlation

Variables and Measurement:

Learning organization is a latent variable measured using 6 variables.
CompetitiveAdvantage is also a latent variable with 5 measureable indicators

\section{Hypotheses:}

H0: Learning organization and competitive advantage is not interrelated

H1: Learning organizations and competitive advantage is significantly related

$\alpha=0.05$ 


\begin{tabular}{|l|l|l|l|l|l|l|l|}
\hline Sr No. & Correlation & Eigenvalue & Wilks Statistic & F & Num D.F & Denom D.F. & Sig. \\
\hline 1 & .817 & 2.013 & .181 & 2.809 & 30.000 & 158.000 & .000 \\
\hline 2 & .623 & .635 & .545 & 1.341 & 20.000 & 133.615 & .164 \\
\hline
\end{tabular}

- Since $\mathrm{p}=0.05$, null hypotheses is rejected and it is concluded that the two variables are inter related

- $\mathrm{R}^{2}=0.67$; This indicates that Learning Organization can explain $67.8 \%$ of the Competitive advantage variables

\section{H3: Learning organizations and financial performance is significantly related}

\section{Statistical test: Path analysis}

Path analysis is a minor version of structural equation model. It is an advanced statistical technique used to study several variables simultaneously. It is a family of equations since it can handle several relationships in a single analysis. In the current study Path analysis is used to establish relationship between variables: Organizational Environment, External Connect, Entrepreneurial Orientation, Knowledge Management, Organizational learning, Transformational leadership, Competitive Advantage, Retention, Financial performance.

The following path diagram indicates hypothetical path between the variables:

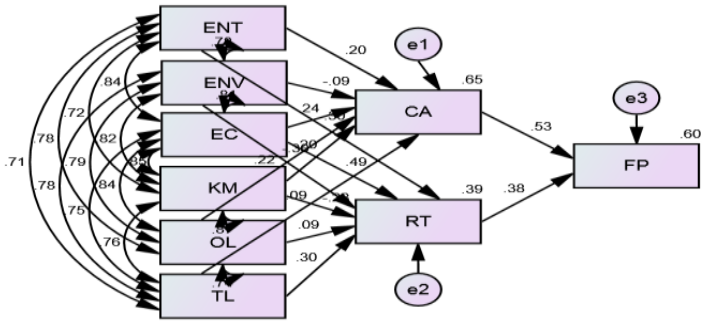

From the above 'Path diagram' it can be seen that Knowledge Management, Organizational learning and Transformational leadership are significant predictors of Retention and Organizational Environment, External Connect, Entrepreneurial Orientation are significant predictors of Competitive advantage. Competitive advantage and Retention is a significant predictor of financial performance.
Model Fit Summary: Path Analysis

\begin{tabular}{|c|c|c|c|}
\hline Fit Indices & Observed & $\begin{array}{l}\text { Criteria of } \\
\text { Acceptance }\end{array}$ & Result \\
\hline $\begin{array}{l}\text { CMIN/DF } \\
\text { (Minimum } \\
\text { discrepancy as } \\
\text { indexed } \\
\text { chi-square) }\end{array}$ & 3.146 & Less than 5 & $\begin{array}{l}\text { Acceptable } \\
\text { fit }\end{array}$ \\
\hline $\begin{array}{l}\text { CFI } \\
\text { (Competitive } \\
\text { Fit Index) }\end{array}$ & 0.966 & $\begin{array}{l}\text { More than } 0.9 \\
\text { for good fit, } \\
\text { between } 0.9 \\
\text { to } 0.8 \text { for } \\
\text { borderline fit }\end{array}$ & $\begin{array}{l}\text { Acceptable } \\
\text { fit }\end{array}$ \\
\hline $\begin{array}{l}\text { GFI } \\
\text { (Goodness of } \\
\text { Fit index) }\end{array}$ & 0.920 & More than 0.9 & $\begin{array}{l}\text { Acceptable } \\
\text { fit }\end{array}$ \\
\hline $\begin{array}{l}\text { RMR(Root } \\
\text { mean } \\
\text { residual) }\end{array}$ & 0.054 & $\begin{array}{l}\text { Less than } \\
0.08 \text { for } \\
\text { adequate fit, } \\
\text { between } 0.08 \\
\text { and less than } \\
0.1 \\
\end{array}$ & $\begin{array}{l}\text { Acceptable } \\
\text { fit }\end{array}$ \\
\hline & & & \\
\hline
\end{tabular}

All the above Fit indices suggest a good fit between sample data and hypothetical model

Assessing the significance of the paths

The hypothetical paths are tested for significance using standardized regression rates and 'p'value.

Factor loading is an important indicator of convergent validity. Factor loading that are significant and with a value more than 0.5 confirms validity of the construct. The following table shows factor loading and significance values for items of the construct. 


\begin{tabular}{|l|l|l|l|}
\hline RT <--- KM & Knowledge management on retention & -0.275 & 0.314 \\
\hline RT <-- EC & External Connect on retention & 0.486 & 0.072 \\
\hline RT <--- ENV & Environment on retention & -0.298 & 0.200 \\
\hline RT <-- ENT & Entrepreneurial Orientation on retention & 0.296 & 0.191 \\
\hline FP <--- CA & Competitive advantage on FP & 0.528 & $* * *$ \\
\hline FP <--- RT & Retention on FP & 0.376 & $* * *$ \\
\hline
\end{tabular}

From the above table it can be seen that though the model fit is good and there is a link between Learning Organizations and Competitive advantage in BPOs. The path results show that Organizational Environment, Entrepreneurial Orientation, Knowledge Management, Organizational learning and Transformational leadership are not significant predictors of Retention and Competitive advantage, except External Connect which is a partial significant predictor of retention. Further Competitive Advantage and retention are significant predictors of Financial Performance.

\section{DISCUSSION AND CONCLUSION}

The current study strengthens the theory that Learning Organizations can influence the overall organizational performance which could be measured in terms of several factors, three of which have been included in the current scope - Competitive advantage gained Employee retention and Financial Performance. Our findings affirm a relationship between Learning Organizations and Competitive advantage, alluding to the value placed on the knowledge workers ability to make a difference in the quality of service delivery and their ability to drive innovation.

The link between Learning Organizations and Employee Retention is also testimony to recent empirical studies that refer to reskilling being the need of the hour in the BPO industry, and this is driving high performers to seek employers who are willing to invest in them through learning opportunities. Needless to stay a happy employee who is satisfied with the current job will be more actively engaged and make a meaningful contribution at work. Findings from this study also confirm past research on how focus on learningand providing self-development opportunities makes an individual stay longer in the current organization and ensure their own performance meets with the organizations expectations (Weldy. 2009).

The results indicate that of the six characteristics of learning organization model in the VUCA world, (Nair.J \& Pahurkar.R, 2017) for the BPO industry, External connect, Entrepreneurial orientation and Organizational Learning are three characteristics of a Learning organization that has the best model fit on all the four parameters- CMIN, CFI, GFI and RMR, when compared with Knowledge Management, Transformational Leadership and Organizational environment. This aligned with responses shared by industry experts on the encouragement offered to employees to come up with innovative solutions, the awareness of what is happening in the world technology and the threat from automation. Opportunities for knowledge sharing too, participating in domain sessions, and mandating time invested in individual skill development strengthen organizational learning.
Digitalization of work by leveraging evolving technology means the way the BPO industry understands work itself is going to going to go through a major change. Automation tools like Automation Anywhere, Blue Prism and several others have simplified the process of automation itself enabling domain process experts to reimaging processes and apply design thinking to simplify the end customer experience. Partial skills needed to do this reside within the BPO industry, it is about who is able to up-skill the non-technical knowledge worker on the new tools. Transparent communication from seniors and access to information has ensured the BPO employees are aware of the need to quickly re-tool to stay relevant, and are there constantly looking for opportunities to do so. A talent pool that can be quickly be deployed on these projects, and has the expertise to advise the client organization on its digital transformation journey can be a major competitive advantage.

As the nature of work changes from low skilled to high skilled activities being performed by a hybrid work force, the change to revenue models and increase in gain share pricing contracts means a direct impact on the financial performance of the organization.

The modern professional learns not only in a classroom or training course, but in several ways. They learn from formal structured events, or from their social interactions (Hart.J, 2019). To retain these high performers who learn not only to meet the mandatory requirements but for constant self-development, learning needs to be integrated into their normal work day. Learning content that is bite sized, on demand, and available on all devices can appeal to all demographics as it aligns perfectly with the adult learning principles (Knowles.M, )

\section{Additional Scope for further research}

Though the reliability and validity of the survey instrument has been achieved it is recommended that a larger sample size covering major cities in India be covered in the next phase of the research. The BPO industry has already embarked on a reskilling journey; hence it will be worthwhile to also assess the level of maturity of the BPO as a Learning Organization. Results for the initial study with a sample size of. 50 indicate a good model fit and 3 paths are significant. To further investigate the model with a larger sample size it is recommended that SEM (structural equation model) be used for the analysis and monitor the improvement in the results. There may be reasons to believe that the focus of learning will be different for each type of BPO, and also vary depending upon the city, since it links with the number of opportunities that may vary in Tier 1, 2 and 3 cities of India. 


\section{REFERENCES}

1. Hult, G. T. M.,Hurley, R. F., \& Knight, G.A. (2004). Innovativeness: Its Antecedents and Impact on Business

2. Cooper, R.G., Edgett, J. , Kleinschmidt, S.J. (2001) Portfolio Management for New Product Development: Results of an Industry Practices Study, R\&D Management (Industrial Research Institute, Inc.) Volume 31, number 4, 2001

3. Erdil, O. and Keskin, H., (2004), The relationships between market orientation, firm Innovativeness and innovation performance, Journal of Global Business and Technology, 1(1), 1-11

4. Rubera, Gaia and Kirca Ahmet H, (2012), "Firm Innovativeness and Its Performance Outcomes: A Meta-Analytic Review and Theoretical Integration," Journal of Marketing, 76(3): 130-147

5. Dougherty Deborah and Hardy Cynthia (1996). Sustained Product Innovation In Large, Mature Organizations: Overcoming Innovation-to-Organization Problems, The Academy of Management Journal, 39/5

6. Porter, M. E. The Competitive Advantage: Creating and Sustaining Superior Performance. NY: Free Press, 1985

7. Barney Jay (1991). Firm Resources and Sustained Competitive Advantage, Journal Of Management, Vol. 17,No 1, 99-120

8. Senge, Peter. 1990. The Fifth Discipline: the Art and Practice of the Learning Organization. New York: Doubleday

9. Garvin, David. Jan. 1994. Building a Learning Organization. Business Credit, Vol. 96, No. 1, pp. 19-28

10. Gephart, Martha A., Victoria J. Marsick, Mark E. Van Buren, and Michelle S. Spiro. Dec. 1996. Learning Organizations Come Alive.Training \& Development, Vol. 50, No. 12, pp. 35-45.

11. Argyris, C. and Schon, D. (1996), Organizational Learning II: Theory, Method and Practice, Addison Wesley Publishing, Reading, MA

12. Nair and Pahurkar, (2016), A Comparative study of Learning Organization models - A critical review, International Research Journal of Management Science \& Technology Vol 7 Issue 12 [Year 2016] ISSN 2250 - 1959 (Online) 2348 - 9367 (Print)

13. Kaufmann, L. and Schneider, Y. (2004), Intangibles: A synthesis of current research, Journal of Intellectual Capital, 5 (3), pp. 366- 388

14. Barney, J. B. 2002.Gaining and Sustaining Competitive Advantage: Prentice Hal

15. Urbano, D., Yordanova, D. (2008). Determinants of adoption of HRM practices in tourism SMEs in Spain: An exploratory study. Service Business, 2, 167-185. doi:10.1007/s11628-007-0033-z

16. Arenas, T.,\& Lavanderos, L., (2008). Intellectual capital: object or process? Journal of Intellectual Capital 9,1, 77-87.

17. Freeman, E and Mcvea, J.( 2001). A stakeholder Approach to strategic management. Working Paper No. 01-02SSRN Electronic Journal • January 2001 DOI: $10.2139 /$ ssrn.263511

18. Watkins, K. E. \& Marsick, V. J. (1999). Facilitating Learning Organizations: Making Learning Count. Aldershot: Gower Publishing Limited

19. Teresa G. Weldy, (2009) "Learning organization and transfer: strategies for improving performance", The Learning Organization, Vol. 16 Issue: 1, pp.58-68, https://doi.org/10.1108/09696470910927678

20. Modern workplace Learning 2019 by Hart.J, 2019: A framework for continuous Improvement, Learning and development at work. Centre for Learning and Performance Technologies

21. The Adult Learner: A Neglected Species by Knowles, M. (3rd Ed.) Houston: Gulf Publishing (1984).

\section{Annexure}

\section{Variables of measurement}

\section{ENTREPRENEIRIAL ORIENTATION (EO)}

\begin{tabular}{|l|l|}
\hline $\begin{array}{l}\text { Latent } \\
\text { Construct }\end{array}$ & Attributes \\
\hline EO1 & $\begin{array}{l}\text { Rewards and recognition program for new } \\
\text { ideas being generated by employees }\end{array}$ \\
\hline EO2 & $\begin{array}{l}\text { Sharing innovative ideas and brain } \\
\text { storming on feasibility and impact }\end{array}$ \\
\hline EO3 & $\begin{array}{l}\text { Measuring Return on Investments from } \\
\text { new ideas before implementation }\end{array}$ \\
\hline EO4 & $\begin{array}{l}\text { Developing forums that encourage } \\
\text { competition and ideation opportunities }\end{array}$ \\
\hline
\end{tabular}

\begin{tabular}{|l|l|}
\hline 2. ORGANIZATIONAL ENVIRONMENT (ENV) \\
\hline $\begin{array}{l}\text { Latent } \\
\text { Construct }\end{array}$ & Attributes \\
\hline ENV1 & $\begin{array}{l}\text { Formal process for idea review and cost } \\
\text { benefit analysis }\end{array}$ \\
\hline ENV2 & $\begin{array}{l}\text { Tolerance for errors and Psychological } \\
\text { safety }\end{array}$ \\
\hline ENV3 & $\begin{array}{l}\text { Amount of time devoted to training by the } \\
\text { employees in a year }\end{array}$ \\
\hline ENV4 & $\begin{array}{l}\text { Trainings that extend beyond current area } \\
\text { of work }\end{array}$ \\
\hline ENV5 & Enabling employees to be 'future ready' \\
\hline
\end{tabular}

3. EXTERNAL CONNECT (EC)

\begin{tabular}{|l|l|}
\hline $\begin{array}{l}\text { Latent } \\
\text { Construct }\end{array}$ & Attributes \\
\hline EC1 & Aware of risks and opportunities \\
\hline EC2 & Leveraging external experts \\
\hline EC3 & Customer connect \\
\hline EC4 & Talent acquisition \\
\hline EC5 & Technology partners \\
\hline
\end{tabular}

4. KNOWLEDGE MANAGEMENT (KM)

\begin{tabular}{|l|l|}
\hline $\begin{array}{l}\text { Latent } \\
\text { Construct }\end{array}$ & Attributes \\
\hline KM1 & Systems and structures to code knowledge \\
\hline KM2 & Database of employee skills \\
\hline KM3 & Leverage technology to share Knowledge \\
\hline KM4 & Recording tacit knowledge \\
\hline KM5 & Multiple sources of knowledge acquisition \\
\hline
\end{tabular}

5. ORGANIZATIONAL LEARNING (OL)

\begin{tabular}{|l|l|}
\hline $\begin{array}{l}\text { Latent } \\
\text { Construct }\end{array}$ & Attributes \\
\hline OL1 & Tolerance for errors \\
\hline OL2 & Team learning \\
\hline OL3 & New Knowledge \\
\hline
\end{tabular}




\begin{tabular}{|l|l|}
\hline OL4 & Effectiveness of learning strategies \\
\hline OL5 & Budget allocation for learning \\
\hline
\end{tabular}

6. TRANSFORMATIONAL LEADERSHIP (TL)

\begin{tabular}{|l|l|}
\hline $\begin{array}{l}\text { Latent } \\
\text { Construct }\end{array}$ & Attributes \\
\hline TL1 & Never reprimand in public \\
\hline TL2 & Experimentation and open discussion \\
\hline TL3 & Articulate a common vision \\
\hline TL4 & $\begin{array}{l}\text { Active listening and joint agreement on } \\
\text { annual Learning goals }\end{array}$ \\
\hline TL5 & Coaching and feedback \\
\hline
\end{tabular}

